\title{
Cellular Membrane
}

National Cancer Institute

\section{Source}

National Cancer Institute. Cellular Membrane. NCI Thesaurus. Code C14070.

Any of the lipid bilayer membranes within a cell. 